\section{In Vitro Evaluation of Anticancer Activity (Efficacy) of a Novel Ayurvedic Polyherbal Formulation on Human Oral Carcinoma Cell Line SCC-40}

\author{
Sandeep Charak ${ }^{1, \odot ~ M o n i k a ~ S h a r m a ~}{ }^{1} \quad$ Sharad M. Porte \\ 1P.G. Department of Agad Tantra, National Institute of Ayurveda,
Jaipur, Rajasthan, India
}

South Asian J Cancer 2021;10:211-212.

We report the efficacy of our ayurvedic polyherbal formulation (V2S2) on human oral carcinoma cell line SCC-40. As you know cancer is a leading cause of death and disability and globally approximately one in six deaths is due to cancer. According to the latest World Health Organization's International Agency for Research in Cancer and the Global Cancer Observatory (GCO) report, ${ }^{1}$ cancer burden has risen to 19.3 million new cases and 10.0 million deaths this year. Surgery, radiotherapy, chemotherapy, and nowadays immunotherapy are commonly available treatments for this disease and recent advanced research studies make these treatments so advance but the world is still struggling for the safe and effective treatment for this deadly disease. Each advanced therapy has many complications, such as chemotherapy has numerous health hazards. The present study indicates that a person dies due more to chemotherapy than cancer. ${ }^{1}$ Thus the world is now looking toward alternative medicines like Ayurveda and Chinese medicine for the treatment of this disease. In Ayurveda the disease which can be correlated and run parallel to cancer is Arbuda. Herbs nowadays get so much importance in cancer therapies because of low toxicity and cost. In this study the anticancer activity of herbal extract V2S2 is studied and compared with control drug Adriamycin, which is an established chemotherapeutic drug. The experimental procedure was performed as per National Cancer Institute $(\mathrm{NCI})$ guidelines and with SRB (sulforhodamine B) assay in TATA Memorial, ACTREC (Advanced Centre for Treatment, Research and Education in Cancer) Mumbai. The Ayurvedic drug code named V2S2 is a hydroalcoholic extract of 10 Ayurvedic herbs processed in a National Institute of Ayurveda pharmacy. The dried extract was then multimilled and sieved through \#40 before packing in moisture-proof triple-layer aluminum pouches. The cell lines were grown in RPMI 1640 medium containing 10\% fetal bovine serum and $2 \mathrm{mM}$ L-glutamine. For the present South Asian J Cancer 2021;10(3):211-212.
Address for correspondence Sandeep Charak, MD Ayurvedic Toxicology (Ayu.), P.G. Department of Agad Tantra, National Institute of Ayurveda, Jaipur 302002, Rajasthan, India (e-mail: dr.sandeep.charak@gmail.com).

screening experiment, cells were inoculated into 96-well microtiter plates at $100 \mu \mathrm{L}$ plating density. ${ }^{2}$ Experimental drugs were initially solubilized in dimethyl sulfoxide at $100 \mathrm{mg} / \mathrm{mL}$ and diluted to $1 \mathrm{mg} / \mathrm{mL}$ using water and stored frozen prior to use. At the time of drug addition, an aliquot of frozen concentrate $(1 \mathrm{mg} / \mathrm{mL})$ was thawed and diluted to $100,200,400$, and $800 \mu \mathrm{g} / \mathrm{mL}$ with complete medium containing the test article. Aliquots of $10 \mu \mathrm{L}$ of these different drug dilutions were added to the appropriate microtiter wells already containing $90 \mu \mathrm{L}$ of medium, resulting in the required final drug concentrations, i.e.,10, 20, 40, and $80 \mu \mathrm{g} / \mathrm{mL}$. After compound addition, plates were incubated at standard conditions for 48 hours and assay was terminated by the addition of cold trichloroacetic acid (TCA). Cells were fixed in situ by the gentle addition of $50 \mu \mathrm{L}$ of cold $30 \%$ $(\mathrm{w} / \mathrm{v})$ TCA (final concentration, 10\% TCA) and incubated for 60 minutes at $4^{\circ} \mathrm{C}$. Percent growth was calculated on a plate-by-plate basis for test wells relative to control wells. Percent growth was expressed as (the ratio of average absorbance of the test well to the average absorbance of the control wells $) \times 100$. Using the six absorbance measurements [time zero $\left(T_{z}\right)$, control growth $(C)$, and test growth in the presence of drug at the four concentration levels $\left.\left(T_{\mathrm{i}}\right)\right]$, the percentage growth was calculated at each of the drug concentration levels. Percentage growth inhibition was calculated as: $\left[T_{\mathrm{i}} / C\right] \times 100 \%$. The anticancer activity of study drug has been measured and compared with Adriamycin, measuring the percentage growth inhibition of human cell line by using a microplate reader. The drug concentration of both study and standard control drugs was used as per guidelines of NCI, such as $10,20,40$, and $80 \mu \mathrm{g} / \mathrm{mL}$. This experiment has been repeated three times and then the average percentage of control growth was calculated and compared.

The average percentage control growth of V2S2 on human oral carcinoma cell line SCC-40 is 42.8 on $10 \mu \mathrm{g} / \mathrm{mL}$,

(c) 2021. MedIntel Services Pvt Ltd.

This is an open access article published by Thieme under the terms of the Creative Commons Attribution-NonDerivative-NonCommercial-License, permitting copying and reproduction so long as the original work is given appropriate credit. Contents may not be used for commercial purposes, or adapted, remixed, transformed or built upon. (https://creativecommons.org/licenses/by-nc-nd/4.0/).

Thieme Medical and Scientific Publishers Private Ltd A-12, Second Floor, Sector -2, NOIDA -201301, India 


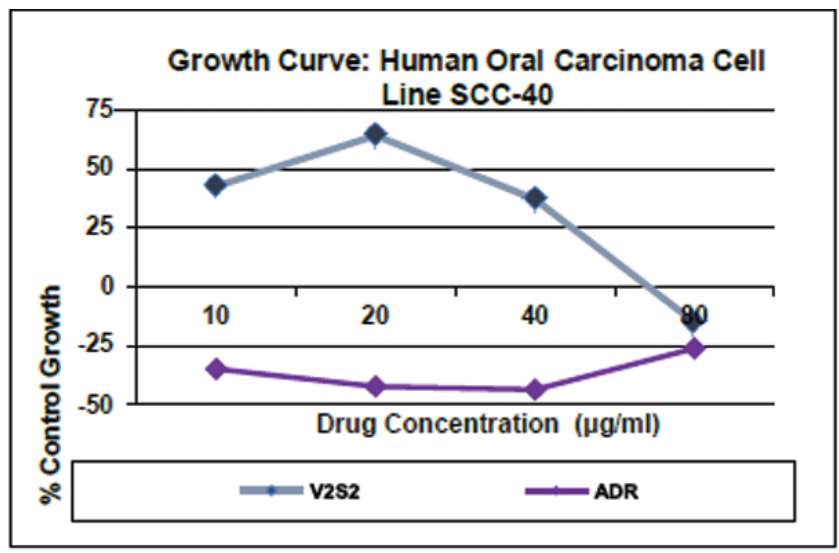

\section{Drug concentrations \\ $(\mu \mathrm{g} / \mathrm{ml})$ calculated \\ from graph}

\begin{tabular}{|c|c|c|c|}
\hline SCC-40 & LC50 & TGI & GI50* \\
\hline V2S2 & NE & 70.0 & $<10$ \\
\hline ADR & NE & NE & $<10$ \\
\hline
\end{tabular}

\begin{tabular}{|l|}
\hline LC50 = Concentration of drug causing $50 \%$ cell kill \\
\hline GI50 = Concentration of drug causing $50 \%$ inhibition of cell growth \\
\hline TGI = Concentration of drug causing total inhibition of cell growth \\
\hline ADR = Adriamycin, Positive control compound \\
\hline $\begin{array}{l}\text { The residual compound with ACTREC will be retained for one month from the date of this } \\
\text { report. Enquiries regarding report will not be entertained after this date. }\end{array}$ \\
\hline NE $\begin{array}{l}\text { Non- evaluable data. Experiment needs to be repeated } \\
\text { using different set of drug concentrations. }\end{array}$ \\
\hline Note: Enratic data can result due to less solubility of the compound. \\
\hline $\begin{array}{l}\text { GI50 value of } \leq 10^{\wedge}-6 \text { molar (i.e. } 1 \mu \text { molar) or } \leq 10 \mu g / m l \text { is considered to demonstrate } \\
\text { activity in case of pure compounds. For extracts, GI50 value } \leq 20 \mu \mathrm{g} / \mathrm{ml} \text { is considered to } \\
\text { demonstrate activity }\end{array}$ \\
\hline Yellow highlighted test values under GI50 column indicate activity. \\
\hline
\end{tabular}

Fig. 1 Effect of different concentrations of V2S2 and Adriamycin on human oral cancer cell line SCC-40.

64.1 on $20 \mu \mathrm{g} / \mathrm{mL}$, 37.1 on $40 \mu \mathrm{g} / \mathrm{mL}$, and -15.2 on $80 \mu \mathrm{g} / \mathrm{mL}$. The GI50 is $\leq 10$ and TGI (tumor growth inhibition) is 70.0. The average percentage control growth of Adriamycin on SCC-40 is -34.9 on $10 \mu \mathrm{g} / \mathrm{mL},-42.4$ on $20 \mu \mathrm{g} / \mathrm{mL},-43.7$ on $40 \mu \mathrm{g} / \mathrm{mL},-26.1$ on $80 \mu \mathrm{g} / \mathrm{mL}$, and GI 50 is $\leq 10$. According to guidelines of NCI, a GI50 value of $\leq 10^{-6}$ molar (i.e., $1 \mu$ molar) or $\leq 10 \mu \mathrm{g} / \mathrm{mL}$ is considered to demonstrate activity in case of pure compounds. For extracts, GI50 value $\leq 20 \mu \mathrm{g} / \mathrm{mL}$ is considered to demonstrate activity. In this experiment, the GI50 of Adriamycin was been found to be $\leq 10 \mu \mathrm{g} / \mathrm{mL}$, which is a pure compound, while the GI50 of V2S2 also showed the same values while it is a hydroalcoholic extract. It means that the Ayurvedic coded drug equally activates on human oral cancer cell line SCC40 when compared with Adriamycin.
Thus V2S2 may be proved to be a potent anticancer drug in future without any toxicity or with minimum toxicity compared with conventional drugs.

\section{Conflict of Interest}

None.

\section{References}

1 Wallington M, Saxon EB, Bomb M, et al. 30-day mortality after systemic anticancer treatment for breast and lung cancer in England: a population-based, observational study. Lancet Oncol 2016;17(9):1203-1216

2 Vichai V, Kirtikara K. Sulforhodamine B colorimetric assay for cytotoxicity screening. Nat Protoc 2006;1(3):1112-1116 